\title{
A case of leucism in the burrowing owl Athene cunicularia (Aves: Strigiformes) with confirmation of species identity using cytogenetic analysis
}

\author{
Denise M. Nogueira' \& Maria Alice S. Alves ${ }^{2}$
}

\author{
${ }^{1}$ Departamento de Genética, Universidade Federal Rural do Rio de Janeiro. Rodovia BR 465, km 7, 23890-000 Seropédica, \\ RJ, Brazil. \\ ${ }^{2}$ Corresponding author. Departamento de Ecologia, Universidade do Estado do Rio de Janeiro. Rua São Francisco Xavier 524 , \\ 20550-011 Rio de Janeiro, RJ, Brazil. E-mail: masaal@globo.com
}

\begin{abstract}
Leucism is an inherited disorder, characterized by the lack of pigments in part or all of the body, normal coloration of the eyes and, in birds, in naked parts such as the bill and legs. This kind of disorder is sometimes erroneously designated as albinism or partial albinism. In this study, we present a case of leucism in a wild owl. The studied individual presented completely white plumage, light-yellow coloration of legs and bill and normal coloration of eyes. According to morphological features, this owl is a specimen of burrowing owl, Athene cunicularia (Molina, 1782). To confirm the species identity, we used cytogenetic analyses for karyotypic determination, comparing it to the previously described one in the literature. We also studied a captive female of $A$. cunicularia to complement the species karyotype, which was described in the literature based only on a single male. The karyotype of the leucistic owl individual was compatible with the previously published one for $A$. cunicularia, confirming the bird was a male specimen. Cytogenetic analysis of the captive female showed that the $\mathrm{W}$ sex chromosome is metacentric and comparable to the seventh pair in size. This is the first description of a case of leucism in A. cunicularia for South America. Long-term studies are needed in the Neotropical region to evaluate survival and breeding success in leucistic birds.
\end{abstract}

KEY WORDS. Aberrant plumage; bird; chromosomes; karyotype.

Inherited color defects, such as albinism and leucism, are well known in several animal species. In birds, leucism is distinguished by complete lack of melanin in some or all feathers, without color changing in naked parts of the body such as eyes, beak and legs (BuCKLey 1982). In some cases, leucistic birds can show decreased pigmentation in the beak, legs and in some parts of the eye, although it differs from an albino because it shows dark pupil, once pigments in the rear part of the eyeball are present (VAN GROUw 2006). The presence of pure white feathers over a large portion of the bird's head, in areas where typical birds have colored feathers, is apparently a common form of leucism previously observed in some species of Troglodytidae, Furnariidae, Rhinocryptidae, Thraupidae, Turdidae, Emberizidae e Parulidae (Kratter \& Nice 2001, Nemésio 2001, Piacentini 2001, Krabbe \& Schulenberg 2003, Kroodsma \& Brewer 2005, Hosner \& Lebbin 2006, Lebbin et al. 2007, Cestari \& Costa 2007, Gonçalves JR et al. 2008, Franz \& Fleck 2009). The causes of leucism are often attributed to the expression of mutant alleles (Bensch et al. 2000) or deviations of gene expression which disrupt the pigmentation at feather development (Møller \& Mousseau 2001). Alternatively, such cases may result from physiological disturbance (Phillips 1954). The proximate cause of albinism is a hereditary trait due to a single autosomal recessive gene that causes the lack of activity of the enzyme tyrosinase, a key com- ponent of the pathway leading to the formation of melanin (GrønsKov et al. 2007). Albinism is defined by the complete loss of all pigments in plumage and other body parts, resulting in birds with white plumage and a lack of pigment in their eyes, beak, skin, legs and feet (Hosner \& Lebirn 2006). Reduction of melanin in the eyes results in reduced visual acuity (GrønsKov et al. 2007). However, in cases of leucism the eyesight is normal (VAN GROUw 2006).

There are, in the literature, cases of many specimens of birds with white plumage erroneously classified as incomplete or partial albinos (Gross 1965, Oliveira 1983, Coelho \& Alves 1991, Møller \& Mousseau 2001, Dowding \& Gummer 2003, GoNŹ́LEZ-AcuÑa 2004) but which are really cases of leucism. Since melanin is present in some parts of the body, the terms partial or incomplete albinism is not appropriate (BUCKLEY 1982, Nemésio 1998, 1999, 2001, van Grouw 2006). Buckley (1982) suggests that the white morphs in polymorphic species may have resulted from leucism, which also could be responsible for the origin of the white monomorphic species like the egrets.

It is thought that the absence of pigmentation results in low life expectancy, since these individuals would be more exposed to predation and to intraspecific conflict (Holt et al. 1995). In the case of albinism, those effects would be more severe and, therefore, it would be sporadically found in na- 
ture. The absence of pigmentation would increase the chances of being predated and there is a greater tendency for malignant skin tumors. There are also eye diseases associated with albinism that reduce visual acuity and therefore make it difficult to locate prey and predators (GRøNSKOv et al. 2007).

In this study, we present a case of leucism in the burrowing owl, Athene cunicularia (Molina, 1782). This species is distinguished by brown plumage tinged reddish, bright yellow eyes, yellowish beak and legs with an average total length of $23 \mathrm{~cm}$. Unlike most owls, burrowing owls are often active during the day. They range from Canada through Tierra del Fuego and are present in almost all the Brazilian territory (Sіск 1997).

The objectives of the present work were to describe a case of leucism in the burrowing owl, to confirm the species by cytogenetic analysis, and to analyze a A. cunicularia female to complete the karyotype description of the species.

\section{MATERIAL AND METHODS}

The owl specimen was found in October 2008 at a vivarium in the Parque Natural Municipal do Pássaros, located at Rio das Ostras municipality, Rio de Janeiro, to where it was brought after being captured (anonymously) near the restinga habitat (sandy plains covered by a mosaic of plant communities) of the Rio das Ostras municipality. The morphological features suggested that the individual was an A. cunicularia. For cytogenetic analysis, young feather pulps (SANDNESs 1954) and lymphocytes from peripheral blood cultures (MOORHEAD et al. 1960) were taken. The chromosomes were stained with $3 \%$ Giemsa in phosphate buffer $\mathrm{pH}$ 6.8, and examined in a Zeiss Axioskop microscope at $100 \mathrm{x}$ magnification. The best metaphases were recorded with a digital camera and the karyotype was edited using Adobe Photoshop CS3 software. The description of the chromosome morphology was based on Levan et al. (1964). The karyotypic analysis of a captive female from the RIOZOO Foundation was also performed to describe the morphology of the $\mathrm{W}$ sexual chromosome and complete the species karyotype.

\section{RESULTS}

The owl specimen studied exhibited entirely white plumage, normal coloration of the eyes (yellow iris), legs and beak, although brighter than observed in individuals with normal plumage coloration. The morphological features suggest that the individual in question is an A. cunicularia (Fig. 1).

The cytogenetic analysis of the leucistic owl confirmed the species identity, revealing a diploid number of $2 n=84$ chromosomes, comprising 14 macro-chromosomes and 70 microchromosomes. Chromosome pairs 1, 2, 3, and 5 are acrocentrics and pairs 4 and 6 are metacentrics as is the sexual pair ZZ (Fig. 2). The karyotype of the female specimen from captivity revealed that the $\mathrm{W}$ chromosome is metacentric comparable in size with the seventh chromosome pair (Fig. 3).

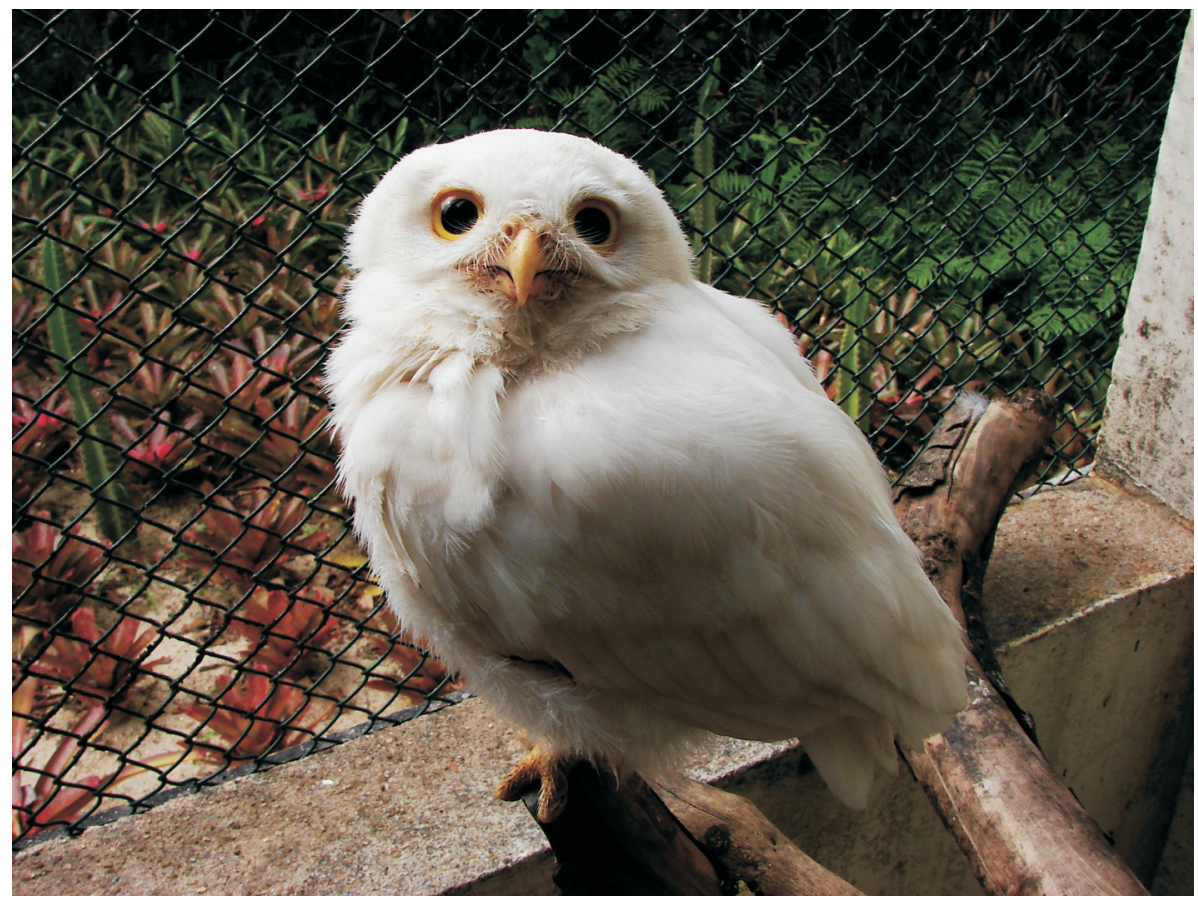

Figure 1. Leucistic A. cunicularia, pure white with eyes, beak and legs of normal coloring, found in the Rio das Ostras vivarium, Rio de Janeiro. Photo: Edvandro A. Ribeiro. 


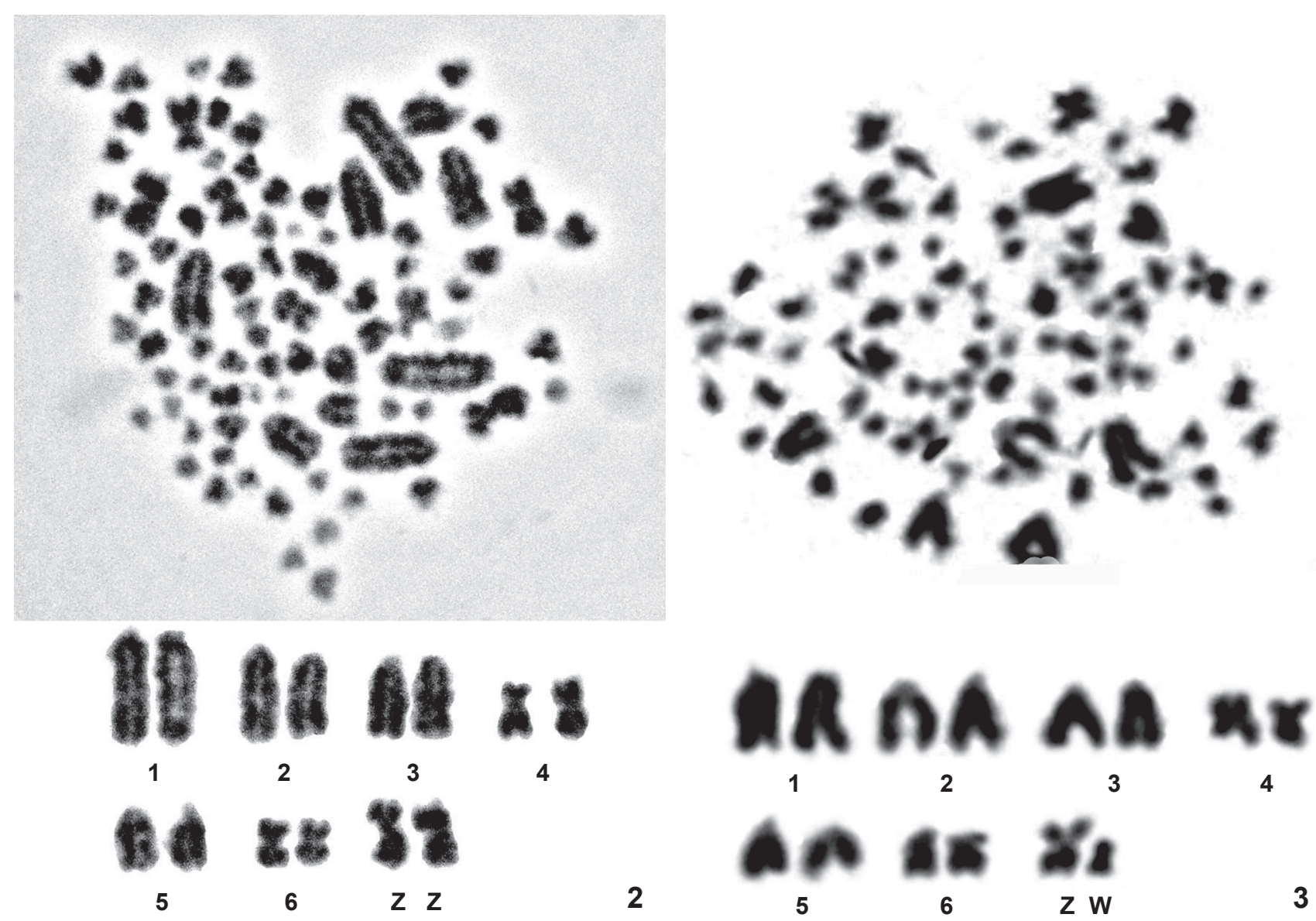

Figures 2-3. Metaphase and karyotype of: (2) a male of $A$. cunicularia with leucism, $2 \mathrm{n}=84, \mathrm{ZZ}$; ( 3 ) a female of $A$. cunicularia, $2 \mathrm{n}=84$, $\mathrm{ZW}$. The sexual $\mathrm{W}$ chromosome is metacentric and comparable in size with the seventh pair.

\section{DISCUSSION}

This is the first description of leucism in A. cunicularia for South America. Albinism and leucism in owls is rare (Gross 1965, Alaja \& Mikrola 1997). Cases of leucism (considered as partial albinism) have already been reported for $A$. cunicularia (Sutton 1912, Alaja \& Mikкola 1997), as well as for other species, such as: Bubo virginianus (Gmelin, 1788) (SPOFFord 1952); Asio flammeus (Pontoppidan, 1763) (SAGE 1883); Otus kennicottii (Elliot, 1867) (Holt et al. 1995), Athene noctua (Scopoli, 1769) (SAYERS 1996), Pulsatrix perspicillata (Latham, 1790) (SAYERS 1996), and Strix nebulosa Forster, 1772 (Alaja \& Mikкola 1997). Gross (1965) reported nine cases considered as partial or complete albinism in five species of owl from North America, without mentioning which species.

In the present study, the karyotype found for the leucistic owl was compatible with the one published by Reвноlz et al. (1993), confirming that the individual is an A. cunicularia male. These authors published the partial karyotype of $A$. cunicularia, since only a male was studied, where it was found to have a diploid number ranging from 82 to 86 , comprising seven pairs of macro-chromosomes (being 12 autosomes and the sexual pair) and 72 micro-chromosomes. The autosome pairs 1, 2, 3, and 5 are acrocentrics and the pairs 4 and 6 are metacentrics, as well as the $\mathrm{Z}$ sexual chromosome. With the study of only one male, it was not possible to describe the morphology of the $\mathrm{W}$ sexual chromosome that is solely present in females. The analysis of the captive female complemented the karyotype description of the species.

The occurrence of leucistic birds in natural populations rarely exceeds 1\% (SAGE 1963, SANTOS 1981, BensCh et al. 2000). Elevated frequencies of leucism were registered in inbred populations by BENSCH et al. (2000), who found an occurrence of $4.5 \%$ in a recently founded population of Acrocephalus arundinaceus (Linnaeus, 1758) in Sweden. Beside that, in a particular situation, after the Chernobyl nuclear accident, a 13 to $15 \%$ leucism rate was detected in a population of Hirundo rustica Linnaeus, 1758 (Ellegren et al. 1997, Møller \& Mousseau 2001). 
One of the consequences of leucism, the reduction of life span due to intraspecific conflict, is mostly observed for species living in flocks (Harris 1983, Withgott \& McMahon 1993). In the present case, given their non-gregarious social behavior, the owls seem to be less affected by intraspecific harassment than other bird species. Considering that the burrowing owl has diurnal habits, the conspicuous nature of the leucistic individuals can make them more vulnerable to predation (Santos 1981, Pomarede 1991, Alaja \& Mikrola 1997, Ellegren et al. 1997, Colurns 2003). When the leucistic individual is itself a predator, this can reduce its foraging success, since unobserved approach on their prey may be less likely (Alaja \& MikKola 1997). However, in some cases of leucism, the birds survived and reproduced successfully over long periods in the wild (ALAJA \& Mikrola 1997, Forrest \& Naveen 2000).

In some species, the white plumage can be associated to a specific stage of life and after subsequent molt the white feathers are replaced by normal colored ones. The developmental physiology of A. cunicularia is well known and there is no mention in the literature about the occurrence of white plumage in juveniles or chicks that could be replaced by molting.

In 16 cases of albinism and leucism in several species of owl reported by Alaja \& Mikкola (1997), the individuals paired normally and survived several years in the wild. Long-term studies in the Neotropical region are necessary to evaluate if the breeding success and survival of the bird species with leucism are similar to that registered for regions with temperate weather, where the snow in winter can make its detection difficult.

\section{ACKNOWLEDGEMENTS}

We thank Edvandro A. Ribeiro for finding the owl and taking its blood sample for the genetic analysis, and Clinton N. Jenkins for reviewing this paper. Carlos A.R. Matias and the staff of the Parque Natural Municipal dos Pássaros, located at Rio das Ostras municipality, gave us information about the leucistic owl and assistance with blood collection. Luiz Paulo Fedullo, from the RIOZOO Foundation took the blood sample from the captive burrowing owl female. Deodato de Souza and Josh Boyer contributed with scanned copies of old papers included in this work, and Beatriz Goldschmidt helped with the microscopic analysis. We also thank CNPq (Proc. 302718/2003-6) and FAPERJ (Proc. E-26/102.868/2008) for the Research Grant to MASA.

\section{LITERATURE CITED}

Alaja, P. \& H. Mikкola. 1997. Albinism in the Great Gray Owl (Strix nebulosa) and other owls, p. 33-37. In: J.R. DunCAN; D.H. JoHNSON \& T.H. NichOlLs (Eds). Biology and conservation of owls of the Northern hemisphere. Washington, D.C., USDA Forest Service, General Technical Report NC-190, 632p.

Bensch, S.; H. Bengt; D. Hasselquist \& B. Nielsen. 2000. Partial albinism in a semi-isolated population of Great Reed Warblers. Hereditas 133 (2): 167-170.
Buckley, P.A. 1982. Avian genetics, p. 21-110. In: M.L. Petrak (Ed.). Diseases of cage and aviary birds. Philadelphia, Lea and Febiger, $2^{\text {nd }}$ ed. $528 \mathrm{p}$.

Cestari, C. \& T.V.V. Costa. 2007. A case of leucism in Southern Lapwing (Vanellus chilensis) in the Pantanal, Brazil. Boletin de la Sociedad Antioqueña de Ornitologia/SAO 17 (2): 145-147.

Coelho, E.P. \& V.S. Alves. 1991. Um caso de albinismo em Sula leucogaster na ilha de Cabo Frio, Rio de Janeiro (Pelecaniformes: Sulidae). Ararajuba 2 (1):85-86.

Collins, C.T. 2003. A leucistic Willet in California. Western Birds 34 (2): 118-119.

Dowding, J.E. \& H. Gummer. 2003. A partial albino Shore Plover (Thinornis novaeseelandiae) on South East Island, Chatham Islands. Notornis 50: 52-53.

Ellegren, H.; G. Lindgren; C.R. Primmer \& A.P. Møller. 1997. Fitness loss and germline mutations in Barn Swallows breeding in Chernobyl. Nature 389 (6651): 593-596.

Franz, I. \& R. Fleck. 2009. Dois casos de leucismo em Queroquero, Vanellus chilensis (Molina, 1782) no sul do Brasil. Biotemas 22 (1): 161-164.

Forrest, S.C. \& R. Naveen. 2000. Prevalence of leucism in pygocelid Penguins of the Antarctic peninsula. Waterbirds 23 (2): 283-285.

Gonçalves JR, C.C.; E.A. Silva; A. C. De Luca; T. Pngiluppi \& F.B. Molina. 2008. Record of a leucistic rufous-bellied thrush Turdus rufiventris (Passeriformes, Turdidae) in São Paulo city, Southeastern Brazil. Revista Brasileira de Ornitologia 16 (1): $72-75$.

GonZÁLeZ-AcuÑa, D. 2004. Albinismo en un ejemplar de Zenaida auriculata (Des Murs, 1847) en Nuble. Boletín Chileno de Ornitología 10: 25-26.

Grønskov, K.; J. Eк \& K.Brondum-Nielsen. 2007. Oculocutaneous albinism. Orphanet Journal of Rare Diseases 2 (43): 1-8.

Gross, A.O. 1965. The incidence of albinism in North American birds. Bird-banding 36 (2): 67-71.

Harris, R.D. 1983. Albinistic Red-breasted Sapsucker. Western Birds 14 (3): 168.

Holt, D. W.; M.W. RoberTson \& J.T. Ricks. 1995. Albino eastern screech-owl, Otus asio. Canadian Field Naturalist 109 (1): 121-122.

Hosner, P.A. \& D.J. Lebbin. 2006. Observations of plumage pigment aberrations of birds in Ecuador, including Ramphastidae. Boletín de la Sociedad Antioqueña de Ornitologia/SAO 16 (1): 30-43.

Krabbe, N.K. \& T.S. Schulenberg. 2003. Family Rhinocryptidae (Tapaculos), p. 748-787. In: J. Del Hoyo; A. Elliott \& D.A. CHRistie (Eds). Handbook of the Birds of the World. Barcelona, Lynx Edicions, vol. 8, 845p.

Kratter, A.W. \& B. Nice. 2001. A partial albino Red-legged Honeycreeper Cyanerpes cyaneus in Costa Rica. Cotinga 15: 15-16.

Kroodsma, D.E. \& D. Brewer. 2005. Family Troglodytidae (Wrens), p. 356-447. In: J. Del Hoyo; A. Elliott \& D.A. Christie (Eds). 
Handbook of the Birds of the World. Barcelona, Lynx Edicions, vol. 10, 896p.

Lebbin, D.J.; W.P. Tori \& A. Bravo. 2007. A Ruddy Spinetail Synallaxis rutilans with aberrant plumage. Cotinga 27: 68-69.

Levan, A.; K. Fredga \& A. Sandberg. 1964. Nomenclature for centromeric position on chromosomes. Hereditas 52 (2): 201-220.

Møller, A.P. \& T.A. Mousseau. 2001. Albinism and phenotype of Barn Swallows (Hirundo rustica) from Chernobyl. Evolution 55 (10): 2097-2104.

Moorhead, P.D.; P.C. Nowell \& W.J. Mellman. 1960. Chromosome preparations of Lymphocyte from human peripheral blood. Experimental Cell Research 20 (3): 613-616.

Nemésio, A. 1998. Herança de cores no periquito-australiano Melopsittacus undulatus. Belo Horizonte, Melopsittacus Publicações Científicas, 168p.

Nemésio, A. 1999. Plumagens aberrantes em Psittacidae neotropicais- uma revisão. Melopsittacus 2 (2/4): 51-58.

Nemésio, A. 2001. Colour production and evolution in parrots. International Journal of Ornithology 4 (2): 75-102.

Oliveira, R.G. 1983. Variação de cor na plumagem do cardealdo-sul (Poroaria coronata Miller, 1776). Anais da Sociedade Sul-Riograndense de Ornitologia 4: 10-12.

Phillips, A.R.K. 1954. The cause of partial albinism in a Greattailed Grackle. Wilson Bulletin 66: 66.

Piacentini, V.Q. 2001. Novos registros de plumagens aberrantes em Muscicapidae e Emberizidae neotropicais. Tangara 1 (4): 183-188.
Pomarede, M. 1991. As mutações e as variedades brancas de aves de gaiola. Atualidades Ornitológicas 40: 13-14.

Rebholz, W.E.R.; L.E.M. De Boer; M. Sasaki; R.H.R. Belterman \& C. Nishida-UmeHaRa. 1993. The chromosomal phylogeny of Owls (Strigiformes) and new karyotypes of seven species. Cytologia 58 (4): 403-416.

SAGE, J.H. 1883. A partial albino Short-eared Owl. Bulletin of the Nuttall Ornithological Club 8: 183.

SAGE, B.L. 1963. The incidence of albinism and melanism in British birds. British Birds 56: 409416.

SAYERS, B. 1996. A personal view of colour mutation. Tyto 1 (1): 24-29.

SANDNESS, G.C. 1954. A new technique for the study of avian chromosomes. Science 119 (3094): 508-509.

SANTOS, T. 1981. Variantes de plumaje y malformaciones en Turdus spp. Ardeola 28: 133138.

Sick, H. 1997. Ornitologia Brasileira: Uma Introdução. Rio de Janeiro, Editora Nova Fronteira, $3^{\text {rd }}$ ed., 862p.

SPOFFORD, W.R. 1952. A partial albino Horned Owl. Kingbird 2 (4): 84.

Sutton, G.M. 1912. An Albinistic Burrowing Owl. Bird Lore 14: 184.

VAN Grouw, H. 2006. Not every white bird is an albino: sense and nonsense about colour aberrations in birds. Dutch Birding 28: 79-89.

Withgott, J.H. \& J.A. McMahon. 1993. Conspecific harassment of a leucistic Barn Swallow. Bulletin of the Oklahoma Ornithological Society 26 (4): 38-39.

Submitted: 10.III.2010; Accepted: 23.XI.2010.

Editorial responsibility: Walter A.P. Boeger 